Published as: Oliver, J.J. and Velji, N. (2018). Are entrepreneurs becoming more risk averse?

Strategic Direction, https://doi.org/10.1108/SD-09-2018-0182

\title{
Are entrepreneurs becoming more risk averse?
}

When you mention the word 'entrepreneur' most people will automatically think of someone who is a risk taker. Our traditional view of entrepreneurs is that they are innovative, opportunists and have a low aversion to risk taking. However, we have observed an interesting trend in the UK Independent TV Production Industry. Entrepreneurs are becoming more risk averse.

\section{The Competitive Dynamics}

Over the past 15 years the UK Independent TV Production Industry has experienced high rates of turbulence, primarily as a result of regulatory and technological change. This unpredictable competitive environment has resulted in a remarkable degree of consolidation with corporate acquisitions and mergers changing the size, shape and revenue distribution amongst firms in the industry. Industry consolidation reduces the number of firms in the industry and concentrates total revenue share in the largest firms at the expense of small or medium sized firms. For example, in 2007 there were 500 independent television production companies in the UK competing for revenues of nearly £2bn. The top 11 firms accrued $14 \%$ of total industry revenues (Ofcom, 2007). The latest figures, from 2014, indicated that there were 250 firms and industry revenues stood at $£ 2.9 \mathrm{bn}$, with the top 10 producers accounting for $66 \%$ of all industry revenues (Ofcom, 2015). The increasing trend for 'scale advantage' will only continue, particularly as smaller, and often weaker firms are acquired in an industry that is characterised by low profit margins.

Whilst entrepreneurs with innovative business ideas are able to enter the industry as a result of low barriers to entry, most of them struggle to compete. Indeed, industry estimates suggest that 80-100 new start-ups enter the industry each year and within months, half of them will go out of business. Access to capital, resources, networks and a lack of business acumen are cited as the key reasons for failure. Self-funding a new start-up, whilst being an option, is now considered to be too risky for creative entrepreneurs.

\section{A new competitive recipe: it's win-win}

As industries mature and consolidate, market revenue growth tends to level out. Equally, as firms scale up, they tend to lose the creativity, innovation and dexterity associated with small entrepreneurial start-ups. We have observed an emerging new trend in the UK Independent 
Published as: Oliver, J.J. and Velji, N. (2018). Are entrepreneurs becoming more risk averse? Strategic Direction, https://doi.org/10.1108/SD-09-2018-0182

TV Production Industry that appears to provide a win-win solution for both large firms and start-ups. Creative entrepreneurs who might previously have been tempted to take a risk and start-up their own independent TV production firm are being given the opportunity to develop their own innovative ideas and brand with the backing of large independent TV production firms. The start-up firm benefits from access to capital, networks, business advice and a low risk environment in which to develop their innovative ideas. The large firm gains access to a new stream of innovative ideas that will hopefully deliver new products and services. On the face of it, this new competitive recipe appears to be a win-win scenario for both parties. Or is it?

\section{The downside of industry consolidation}

In an industry dominated by a handful of large scale TV production companies, competitive rivalry would appear to be less intense than a decade ago. The threat of new entrants in the form of innovative and nimble start-ups is relatively low as a result of a hardening in financing options and the risks associated with self financing. Small to medium sized production firms are equally faced with competing against those large firms with a scale advantage, and as a result, will continue to exit the industry in numbers.

Whilst the 'win-win' scenario mentioned previously allows new start-ups to access a whole range of resources and capabilities to develop creative ideas, the catch is that they don't always own the intellectual property rights to the products that they create; the large firms own it. If the trend in entrepreneurs in the UK TV Production Industry being more risk averse continues, then the number of new start-up firms will fall and that could put the future of the industry at jeopardy.

\section{References}

Ofcom (2007). The Communications Market.

Ofcom (2015). Review of the operation of the television production sector. A report for the Secretary of State for Culture, Media \& Sport (December). 
Published as: Oliver, J.J. and Velji, N. (2018). Are entrepreneurs becoming more risk averse? Strategic Direction, https://doi.org/10.1108/SD-09-2018-0182 